\title{
"KING ARCHIE, WHO WAS QUITE GROUCHY" - A VOCAL DYSPHONIA HEALTH EDUCATION PROJECT
}

\author{
O rei Sebastião que era muito resmungão
}

Maria Rosário Dias ${ }^{(1)}$, Cátia da Silva Pedrosa ${ }^{(2)}$

\begin{abstract}
Purpose: one major cause of dysphonia can be linked to the presence of vocal folds nodules - a condition commonly seen in children due to vocal misuse and/or vocal abuse. The present health education project, also directed to parents and educators, aims at making children (the project's chief target-population) aware of how to make a correct use of their voice. Method: the target population includes parents, educators and children from both sexes and aged between five and eight years old. Result: a health education initiative was developed, which main instrument consists in a children's literature book, supplemented by an interactive CD. The instrument relies on a simple and easy-tofollow story where the issue of child dysphonia is addressed. Conclusions: the developed health education instrument is substantial for its chief target-population; it works as a suitable vehicle for promoting, in children, access, sensibility and awareness regarding aspects of one's voice one should be attentive to.
\end{abstract}

KEYWORDS: Dysphonia; Voice Disorders; Speech Therapy; Voice Training

\section{INTRODUCTION}

The larynx is a significant organ in voice production. The larynx confines several functions, amongst which breathing, deglutition and phonation are especially noteworthy ${ }^{1}$. When breathing, the opening of the larynx ensures the bidirectional flow of air; where phonation is concerned, it stands as an inborn physiological function ${ }^{2}$, although voice undergoes several changes throughout the vital cycle. The voice is the most peculiar form of human communication, with major repercussions in social relations ${ }^{3,4}$. Dysphonia, commonly referred to as hoarseness ${ }^{5-7}$, is characterised by conspicuous vocal effort, with an accompanying shift in voice timbre, which becomes low-pitched and raspy, or

(1) Psychologist; Associate Professor at Egas Moniz, Cooperativa de Ensino Superior; Coordinator of the Egas Moniz Multidisciplinary Research Centre in Health Psychology; Doctor in Clinical Psychology.

(2) Speech Language Therapist. Researcher on Egas Moniz Multidisciplinary Research Centre in Health Psychology.

Egas Moniz - Centro de Investigação Multidisciplinar em Psicologia da Saúde.

Conflict of interest: non-existent strained. The occurrence of this condition in children is associated with speaking loudly and at a fast rate, continuingly (i.e., with no pauses) and during extended periods of time, as well as with reproducing animal sounds and noises. Several authors have pointed out that children presenting vocal alterations of this nature are prone to experience difficulties in communicating or in engaging with their peers ${ }^{2,14-16}$, as well as in making themselves heard and understood in contexts of socialisation ${ }^{17}$.

The identified psychological profile indicates that children affected by dysphonia show, personality-wise, noticeable traits of anxiety, fluctuating aggressiveness, lack of self-control, weak socialisation abilities ${ }^{13-15,17-20}$, a pronounced dependency on others, a poor relation with their parents, and a marked immaturity ${ }^{2,21}$. Parents of dysphonic children report that their child frequently resorts to shouting and yelling when expressing him/herself, is hyperactive, and exhibits low tolerance to frustration.

Relevant literature in the field reports that, although there are school-aged children identified with vocal disorders ${ }^{34-39}$, a considerable number amongst such children is not, paradoxically, referred to or undergoing vocal therapy; to lead parents to acknowledge the importance of seeking help from 
a speech therapist is still somewhat of an ambitious goal. Raising school educators' awareness to this issue is, also, a crucial element, for their awareness will make early identification of children with vocal difficulties possible ${ }^{40}$.

Through the proposed health education project, our purpose is to make parents and educators aware of, and knowledgeable about, pre-emptive strategies aimed at promoting a correct use of voice by their children/students. That said, the preferred target-population, i.e., those the project is set to reach in its first-tier approach, are children aged between five and eight years old. It is to them that we wish to convey the notion that vocal misuse and vocal abuse can cause serious vocal modifications; it is to them that we hope to provide incentive that will lead them to change their day-to-day vocal behaviours.

\section{METHOD}

The target-population selected for this project comprises two supplementary sub-groups, namely Parents and Teachers/Educators - two groups who are to be assumed as veritable strategists of health education $^{41}$, in that both play an active and leading role in bringing the child to adopt salutogenic behaviours. Children constituting the target-population should represent both genders, be aged between 5 and 8 years old, and attend kindergarten or elementary school - the paradigmatic stage of hoarseness manifestation due to vocal misuse and/or abuse. Interestingly, incidence of child dysphonia is shown to be more frequent in males than in females, and to occur around 6/7 years of age, when the child begins attending school ${ }^{7}$. The children suffering from dysphonia stand out among their peers for being very energetic, and for shouting and speaking in a very loud voice ${ }^{1,7,14,16}$. When entering school, children naturally expand their relationships circle, which means that, for purposes of relational communication, the use of their voice becomes subject to a higher level of demand. Around this time, children also begin to gain awareness of their "voice" as a vehicle of power and authority before younger children.

The information on projects in health education is not a boarded subject / an issue. Consequently, we decide to refer articles on vocal pathology, symptoms of dysphagia, dysphonia treatment of children's behavioral characteristics associated with dysphonia, vocal health and the importance of play in the treatment of child patients.

\section{LITERATURE REVIEW}

Incidence of dysphonia in children ${ }^{2,8-11}$ represents 6 to $9 \%$ of children regularly attending elementary school. The state that child dysphonia may be caused by nodules (bilateral protrusions) ${ }^{2}$, which more likely causes are mechanical stress, excessive impact force on the vocal folds, constant dehydration, laryngopharyngeal reflux, and inflammations such as allergies and recurrent infections ${ }^{12,13}$.

The vocal folds nodules as belonging in the same category as psychogenic conditions, arguing that children with vocal folds nodules differ from other children at personality and family history levels ${ }^{21}$. It is therefore important for such children to be followed by a multidisciplinary team, and for the therapeutic intervention to be led by a speech therapist ${ }^{3,6}$. In the context of the relation that speech therapist and child established with each other in the visit setting, the former can use play activities to emphasise and mediate the adopted therapeutic ${ }^{9,22-25}$.

The ludic activity, based on the symbolic play, constitutes a natural means of expression for children and supplements and structures thought ${ }^{26,27}$, action and verbal discourse, thus contributing to the development of the child's imaginary world and creativity ${ }^{28,29}$. On this subject, some authors, state that children's play enables them to learn about external reality without requiring specific training or repetition ${ }^{30}$. When seeing children diagnosed with dysphonia, speech therapists can thus avail themselves of diverse ludic materials, such as games, stories and play activities, creating or adapting instruments to the therapeutic setting ${ }^{16}$.

The pertinence of our intervention project results from the absence, in the reviewed literature, of health education instruments specifically directed to address child dysphonia.

Some studies report that most children (70\%) diagnosed with dysphonia presented with vocal nodules ${ }^{8,31}$. A study points out that, in their favourite play games and activities, children aged between five and seven years old make incessant use of their voice, and that, on the whole, $24,2 \%$ of children engage in voice imitating behaviour when playing. Interestingly enough, they also saw that, while acknowledging that their children displayed abusive voice behaviour, most parents nevertheless considered that their child's voice was normal, and only $18,2 \%$ of parents had sought professional help ${ }^{32}$.

In light of these facts, and given the additional fact the children have no real notion of how important it is to be mindful of their voice, it becomes crucial to involve parents and educators in the acquisition of healthy vocal habits ${ }^{9,16,31,33}$. 
The instrument designed was a children's literature book. Format-wise, the book is shaped as a royal crown, aimed at promoting resource to fantasy and to the symbolic as integral part of children's imaginary world. The content of the narrative, which title is King Archie, who was quite grouchy, assumes that 7-year-olds are already capable of reading, and therefore able to read the instrument autonomously. The instrument also presents itself as contributing to the fostering and instilling of early reading habits. Children under 7 years old can nevertheless also benefit from this instrument; parents and educators are encouraged to use it as a fairy tale book, for both listening to and (re)telling stories significantly enhances the child's verbal resources ${ }^{42}$. Along the same line, the development of an interactive CD, using new technologies, will promote, in a playful manner, reading habits in children who are not inclined to engage in spontaneous reading.

The book cover (hard-cover, in Kapaline) shows the drawing of a castle in the background, and illustrations of some of the story's characters (namely, the King, the Queen, the Fairy.

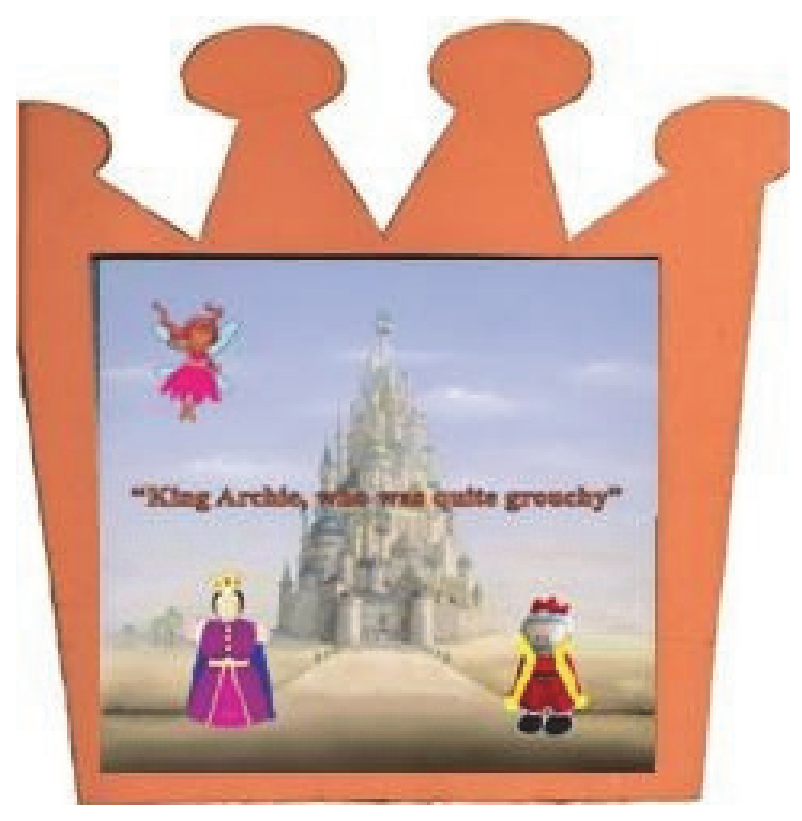

Figure 1 - Book Cover

The tale of the story begins in Scene 2 (Figure 2) with the classical opening "Once upon a time, there was a King who lived in a big castle". The scene illustrates the moment where the counsellor wakes up the King. The action takes place in the King's bedroom chamber; the King is depicted lying in bed with an ill-humoured, grouchy countenance, and the
Royal Counsellor is standing by the King's bed. This scene aims at representing the King's vocal misuse and abuse, showing him "starting his day yelling".

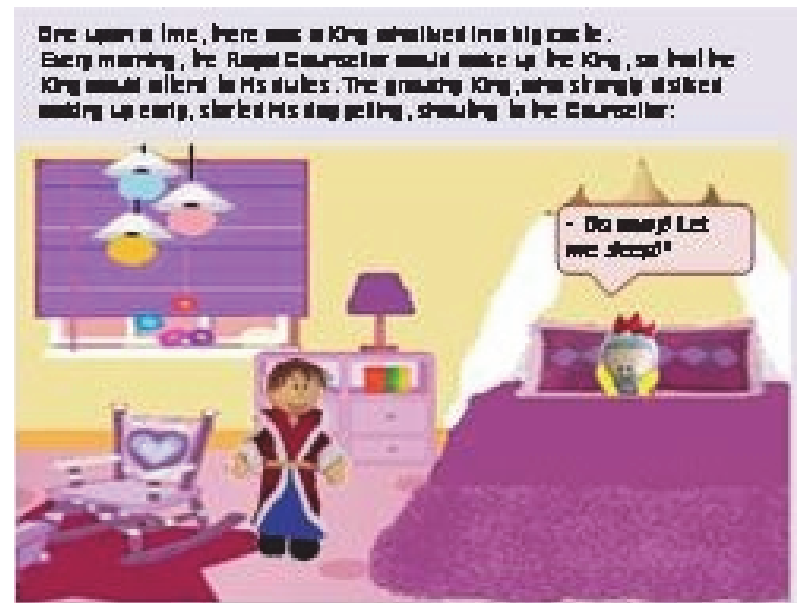

Figure 2 - Scene 2: The counsellor waking up the King

Scene 3 (Figure 3) takes place in the castle's kitchen, showing the cook with a platter on his hand. The King's vocal abuse is once again highlighted: it is mentioned that "even when he was about to have his breakfast, King Archie kept on yelling, and not even the Queen could endure all the King's racket".

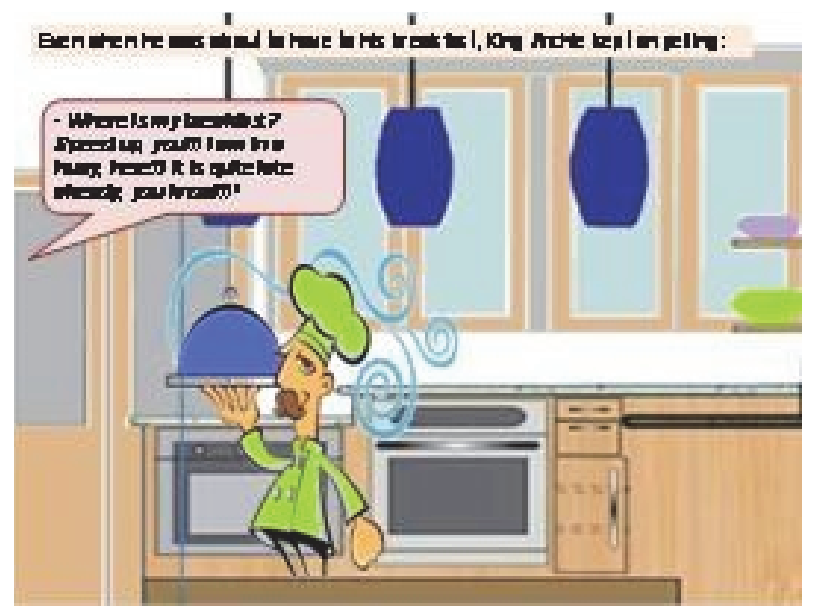

Figure 3 - Scene 3: The cook, on his way to bring breakfast to the King

In Figure 4 (scene 5), the Counsellor is shown to be concerned with the King: His Majesty was taken ill and could not even speak in his customary yelling voice. The Counsellor decides then to send for a doctor to examine the King and appraise his health condition. 


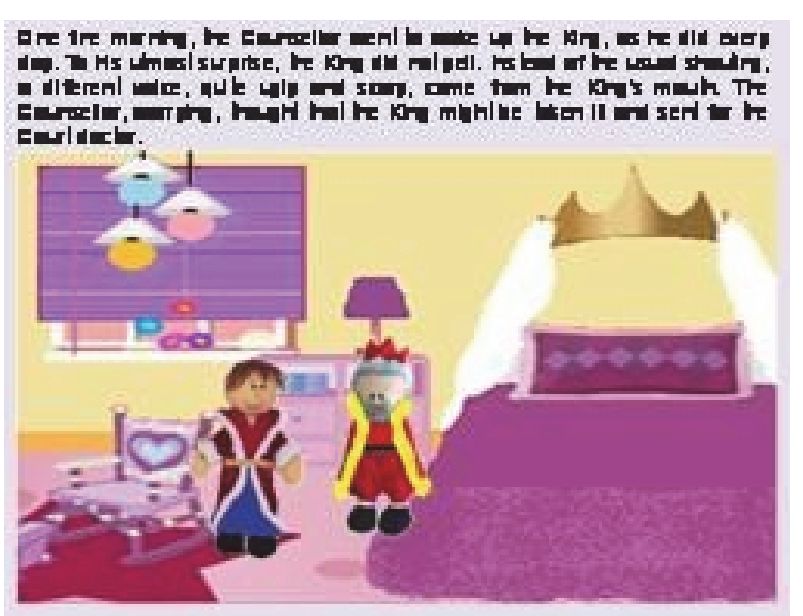

Figure 4 - Scene 5: The Counsellor decides to send for the doctor

From scenes 7 to 14 , the plot is centred on the Court doctor's visit to the King, who expresses grave concern with what was happening to his voice. The doctor then asks the King to open his mouth and proceeds to examine it with a "little mirror", eventually arriving at a diagnosis: there were nodules in the King's vocal folds (scene 9).

In scene 10, the King asks the doctor what nodules and vocal folds are and, in scene 11, the doctor provides a detailed explanation in reply, saying that "when we speak loudly, yell or scream over a long period of time, our vocal folds flap violently against one another, and this causes nodules to appear".

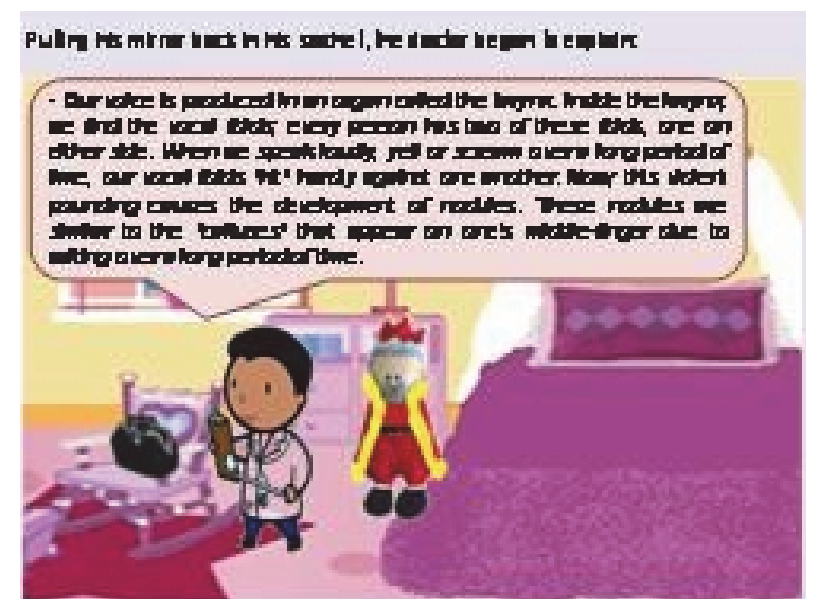

Figure 5 - Scene 11: The doctor enlightens the King on the subject of Vocal Folds
Putting his mirror back in his sachet, the doctor began to explain:

In scene 12, the King inquires the doctor on the seriousness of his clinical condition and on the possibility of ever recovering his voice. In scene 13 , the doctor answers the question confidently, saying that the King's future improvement is specifically contingent on the behaviours His Majesty would choose to adopt in his daily life, in that "were he to persist on yelling, as he did every day, his voice would grow increasingly uglier and unbearable".

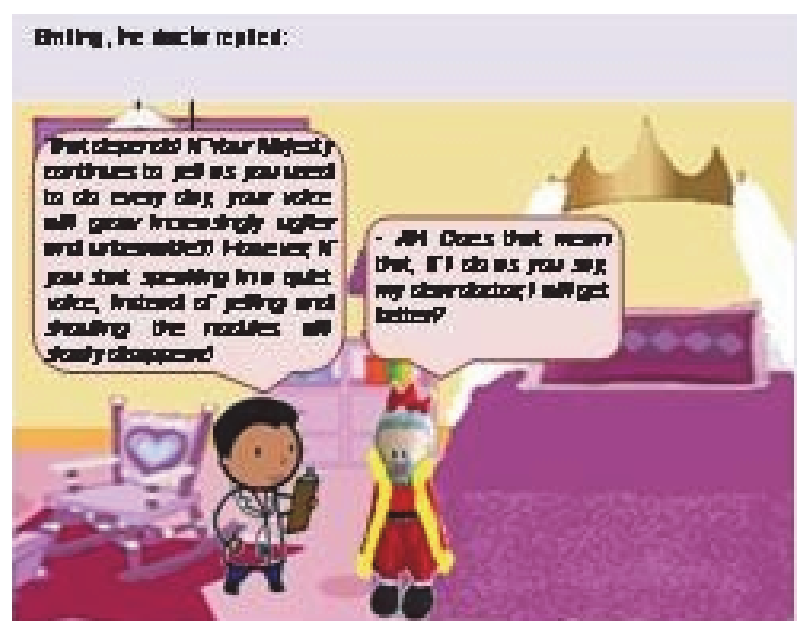

Figure 6 - Scene 13: The King's improvement is contingent on his changing his behaviour

The narrative continues to unfold in the royal chambers, and the Court doctor eventually recommends that the King should enlist the services of a Speech Therapist (scene 14), who will help him improve his vocal use, saying that "this healthcare practitioner will give you advice and teach you phonation exercises".

In scene 15, the King surrenders to his "grouchy condition" and asks the Counsellor to send for a Speech Therapist, so that he can immediately begin speech therapy sessions. Scenes 16 to 18 illustrate the Counsellor sending for the "Speech Therapist Fairy", who will later conduct a vocal assessment and start the recommended therapy.

Scenes 19 (Fig. 7) and 20 represent the King promenading inside his carriage, a few weeks after the treatment. When asked by the "Speech Therapist Fairy" how he was feeling, the King says: "I have followed all your recommendations and performed the vocal exercises you have suggested. My voice is no longer ugly; it has become beautiful again. Nowadays, I no longer yell, shout or grouch. I have even spoken to my Counsellor about creating a new 
law for the Kingdom, where everyone is forbidden to yell or shout because it is bad for one's voice". And so, in keeping with the traditional fairytale ending, "in the Kingdom of the King who ceased to be grouchy, everyone lived happily ever after - and with healthy voices".

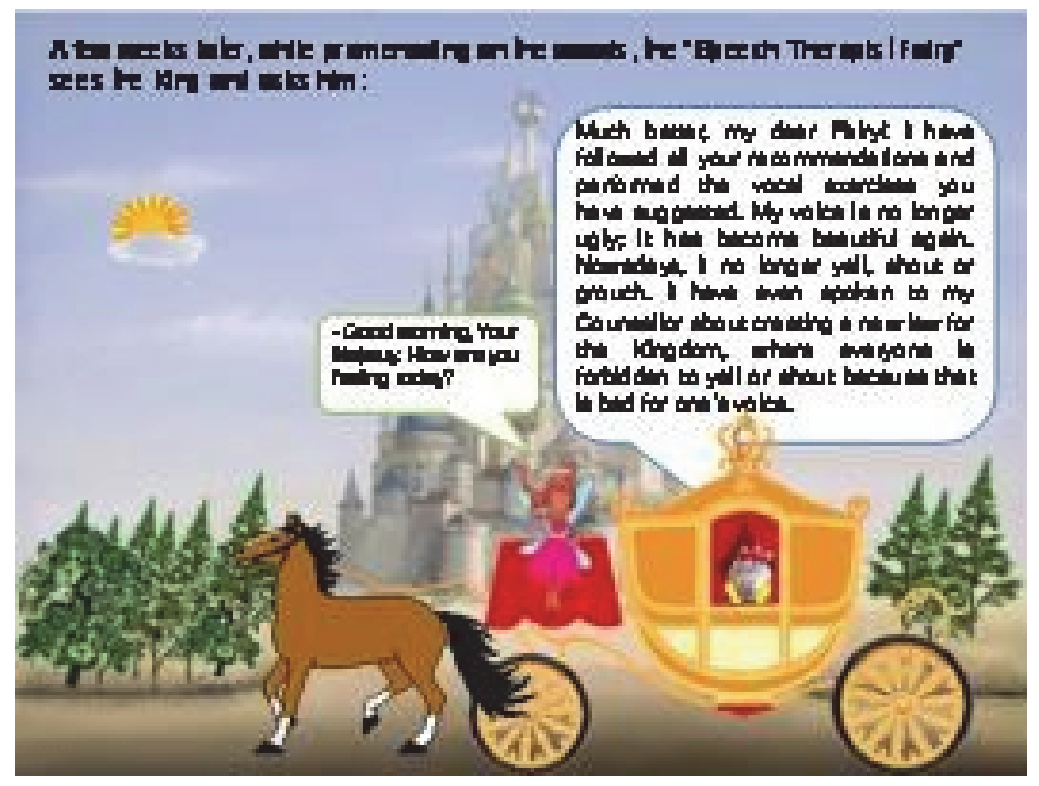

Figure 7 - Scene 19: The King's vocal rehabilitation

\section{CONCLUSION}

The present health education instrument, fashioned as a children's literature book, emerges within the context of creating ludic-pedagogic instruments aimed at restructuring "clinical tools" which can be used in the relational and pedagogic communication established in speech therapy settings. Furthermore, in view of a broader intervention designed to promote vocal health educational in school contexts, the proposed instrument presents itself as a tool anchored in a ludic-relational intervention between parents and children, and between educators and educatees. The story's narrative brings the reader back to the imaginary world of traditional fairytales, which facilitates story retelling and children's comprehension concerning the issue of "vocal misuse and abuse". The option for a fairly tale serves the purpose of making the target-population of the project aware of risk behaviours through a persuasive message, established upon the "symbolic tenor of play activities".

Putting this health education project into practice will show that a close cooperation amongst speech therapist, parents and educators is a crucial element, in that the manifestation of vocal folds nodules qua clinical condition is frequent among school-age children. Considering that those nodules' etiology lies on vocal misuse and vocal abuse, it is relevant to make children sensitive to preventing pathogenic behaviours, such as shouting, yelling and speaking loudly, and, conversely, to instil in them, at an early age, voice protection measures they should be mindful of when playing and interacting with their peers.

The act of playing, itself, holds a symbolic character that enables children to develop learning strategies to cope with those stressful and intimidating circumstances $\mathrm{s} / \mathrm{he}$ will have to face when undergoing speech therapy, for any object or resource can be converted in a toy, or element of an interactive game. The proposed health education project is intended as a means to raise children's awareness, and thus as strategy to preclude vocal pathologies, while at the same time alerting parents and educators to the importance of sound vocal health. Additionally, the review of literature evidences the inexistence of "clinical tools" of interactive-relational character conducive to mediating speech therapy appointments or to achieve vocal health promotion best practices. 


\section{REFERENCES}

1. Behlau, M. Voz: o livro do especialista. Vol. I. Rio de Janeiro: Revinter; 2004.

2. Maia AA, Gama ACC \& Michalick-Triginelli MF. Relação entre transtorno do défit de atenção/ hiperatividade, dinâmica familiar, disfonia e nódulo vocal em crianças. Rev. Ciências Médicas. 2006; 15: 379-89 from http://www.puc-campinas.edu.br/ centros/ccv/revcienciasmedicas/artigos/v15n5a02. pdf.

3. Guimarães I. Ciência e Arte da Voz Humana. $1^{\text {a }}$ edição, Alcabideche: ESSA; 2007.

4. VieiraAC\&BehlauM. Análise devozecomunicação oral de professores de curso pré-vestibular. Rev. Soc. Brasileira de Fonoaudiologia. 2009; 14: 346-51 from http://www.scielo.br/pdf/rsbf/v14n3/v14n3a10. pdf

5. Behlau M \& Pontes P. Avaliação e tratamento das disfonias. São Paulo: Editora Louvise; 1995.

6. Gindri G, Cielo CA \& Finger L. Disfonia por nódulos vocais na infância. Salusvita. 2008; 27: 91-110 from http://www.slideshare.net/jullidias/ salusvita-v27-n12008art08

7. Le Huche F \& Allali R. A patologia vocal de origem funcional. São Paulo: Artmed Editora; 2005.

8. Freitas MR, Weckx LLM \& Pontes PAL. Disfonia na infância. Rev Bras. de Otorrinolaringol. 2000; 66: 257-65.

9. Gielow I. Disfonia Infantil: Terapia da disfonia infantil e o processamento auditivo. Vox Brasilis. 2003; 9: 13 from http://www.ablv.com.br/vox/ vox\%207\%20-\%20pdf.pdf

10. Hersan R. Disfonia Infantil: A disfonia típica da infância. Vox Brasilis. 2003; 9: 12 from http://www. ablv.com.br/vox/vox\%207\%20-\%20pdf.pdf

11. Koishi HU. Disfonia Infantil: Avaliação e tratamento otorrinolaringológico na disfonia infantil. Vox Brasilis. 2003; 9:10 from http://www.ablv.com. br/vox/vox\%207\%20-\%20pdf.pdf

12. Pontes $\mathrm{P}$, Kyrillos L, Behlau M, Biase $N$ \& Pontes P. Vocal nodules and laryngeal morphology. Jounal of voice. 2002; 16: 408-14 from http://www.sciencedirect.com/science? ob=ArticleURL\&_udi=B7585-488XV1P-D\& user $=7740324 \&$ _coverDate $=09 \% 2 F 30 \% 2 F 2002 \&$ $r d o c=1 \& \_f m t=h i g h \& \_o r i g=g a t e w a y \&$ origin $=$ gateway \&_sort=d\&_docanchor $=\& v i e w=c \&$ acct $=$ C000072707\&_version $=1 \&$ \&urlVersion $=0$ \& userid $=7740324 \& \mathrm{md} 5=8 \mathrm{e} 5 \mathrm{be} 0 \mathrm{e} 2 \mathrm{a} 5337799 \mathrm{~d} 88 \mathrm{~b} 7 \mathrm{a}$ 2a3179ef5d\&searchtype $=a$

13. Roy N, Holt KI, Redmon S \& Muntz H. Behavioral characteristics of children with vocal fold nodules. Journal of Voice. 2007; 21: 157-68.

14. Aronson A. Psychogenic voice disorders. In Interdisciplinary approach to detection, diagnosis and therapy. Philadelphia: W. B. Saunders Company; 1973.

15. Navas DM. Disfonia Infantil. Vox Brasilis. 2003;9:11-2 from http://www.ablv.com.br/vox/ vox\%207\%20-\%20pdf.pdf

16. Penteado RZ, Camargo AMD, Rodrigues CF, Silva CR, Rossi D, Silva JTC, Silva SLS G. Vivência de voz com crianças: análise do processo educativo em saúde vocal. Distrib. Comum. 2007;19:237-46 from http://www.pucsp.br/revistadisturbios/artigos/ Artigo_547.pdf

17. Connor NP, Cohen SB, Theis SM, Thibeault SL, Heatley DG \& Bless DM. Attitudes of children with dysphonia. Journal of Voice. 2008; 22:197-209.

18. Behlau M \& Gonçalves MIR. Considerações sobre Disfonia Infantil. In: L. P. Ferreira (Org.), Trabalhando a Voz - Vários Enfoques Fonoaudiológicos. São Paulo: Summers editorial; 1987.

19. Boone DR \& McFarlane SC. A voz e a terapia vocal. Porto Alegre: Artes Médicas; 1994.

20. Toohill RJ. The psychosomatic aspects of children with vocal nodules. Arch Otolaryngol. 1975; 101: 591-5.

21. Aronson A. Clinical voice disorders: an interdisciplinary approach. New York: Thieme Medical Publishers; 1990.

22. Fish S \& Shelly J. Cuidado espiritual do paciente. São Paulo: Umhe; 1986.

23. Ricou M, Salgado J, Alves C, Duarte I, Teixeira Z, Barrias J \& Nunes R. A comunicação e a alteração de comportamentos. Psicologia, Saúde e Doenças. 2004; 5: 131-44.

24. Tschudin V. Counselling skills of nurses. London: Bailliére; 1988.

25. Waddington $\mathrm{L}$. The therapy relationship in cognitive therapy: a review. Behavioural and Cognitive Psychoterapy. 2002; 30: 179-91.

26. Dias MR, Cardoso J \& Soares FA. Uma "árvore caixa-ludo" em fisioterapia pediátrica. In I. Leal, \& S. N. Jesus (Orgs), Actas do $6^{\circ}$ Congresso Nacional de Psicologia da Saúde, Lisboa: ISPA; 2006. p. 621-7. 27. Dias $M$, Soares $F$ \& CarrãoL. $O$ Bafo do Gigante: Projecto de Ludoterapia em educação para a saúde. In I. Leal, \& S. N. Jesus (Orgs), Actas do 6ํㅡㄹ Congresso Nacional de Psicologia da Saúde, Lisboa: ISPA; 2006. p. 667-72.

28. Barbosa A. Educação para a saúde: determinação individual ou social? Revista crítica de ciências sociais. 1987; 23: 169-84.

29. Lebovici S \& Diatkine R. Significado e Função do Brinquedo na Criança. Porto Alegre: Artes Médicas; 1988.

30. Macedo L, Petty ALS \& Passos NC. Aprender com jogos e situações-problema. Porto Alegre: Artes médicas; 2000. 
31. Melo ECM, Mattioli FM, Brasil OCO, Behlau M, Pitaluga ACA \& Melo DM. Disfonia infantil: aspectos epidemiológicos. Revista Brasileira de Otorrinolaringologia. 2001; 67: 804-7 from http:// www.scielo.br/pdf/rboto/v67n6/8448.pdf

32. Takeshita TK, Ricz LA, Isaac ML, Ricz H \& Lima WA. Comportamento vocal de crianças em idade pré-escolar. Arq. Int. Otorrinolaringologia. 2009; 13: 252-8 from http://www.arquivosdeorl.org.br/ conteudo/acervo_port.asp? id=624

33. Souza DPD, Silva APBV, Jarrus ME \& Pinho SMR. Avaliação Fonoaudiológica vocal em cantores infanto-juvenis. Rev. CEFAC.2006;8:216-22 from http://www.revistacefac.com.br/revista82/artigo10. pdf

34. Baynes RA. An incidence study of chronic hoarseness among children. Journal of Speech and Hearing Disorders. 1966; 31: 172-6.

35. Senturia BH \& Wilson FB. Otorhinolaryngologic findings in children with voice deviations. Ann Otol. 1968; 77: 1027-41.
36. Shearer WM. Diagnosis and treatment of voice disorders is school children. Journal of Speech and Hearing Dis. 1972; 37: 215-21.

37. Silverman EM \& Zimmer $\mathrm{CH}$. Incidence of Chronic Hoarseness among School-Age Children. Journal of Speech and Hearing Disorders. 1975; 40: 211-5.

38. Warr-Leeper GA, Mcshea RS \& Leeper HA. The incidence of voice and speech deviations in a middle school population. Language, Speech, and Hearing Services in Schools. 1979; 10: 14-20.

39. Wilson DK. Voice problems of Children. Williams and Wilkins; 1979.

40. Andrews ML. Terapia Vocal para crianças: os primeiros anos escolares. Porto Alegre: Artes Médicas; 1998.

41. Dias MR. Serão os mass media Estrategas de Saúde?. Lisboa: Climepsi; 2005.

42. Amarilha M. Estão mortas as fadas? Literatura infantil e prática pedagógica. Petrópolis: Editora Vozes; 1997.
http://dx.doi.org/10.1590/S1516-18462012005000080

Received on: September 02, 2011

Accepted on: January 12, 2012

Mailing Address:

Maria Rosário Dias, Egas Moniz

Centro de Investigação Multidisciplinar em

Psicologia da Saúde, Campus Universitário, Quinta

da Granja, Monte de Caparica

Caparica - Portugal

2829-511

E-mail: mariadorosario.dias@gmail.com 